\title{
Mobile Banking Products and Rural India: An Evaluation
}

\author{
Peter John, \\ Assistant Professor, Post Graduate and Research Department of Commerce, Fatima Mata National College, \\ Kollam, Kerala, India-691001.
}

\begin{abstract}
The Mobile Banking Products and systems have a pivotal role to play in the financial deepening, especially in rural India. The mobile banking systems and products allow a customer to perform banking operations by making use of mobile phones. In most of the developing countries, especially in India, there is more number of mobile connections than bank accounts. The rural India is facing the problem of lack of accessibility to most of the financial and banking products. This paper evaluates the mobile banking products, mechanism, it's relevance in rural India, implementation systems, it's feasibility in the Indian banking Sector, initiatives taken by Indian Banks and Government of India. The focal area of the study is the potential growth of mobile banking, especially in rural India, not the actual growth attained. This is because of the fact that 74 percent of the Indian population living in rural India and only 18 percent of the total banking penetration of India is in rural area. Out of 428 million deposit accounts in the country only $30 \%$ are in rural areas. In India over $30 \%$ of the new mobile phone subscriptions every month are registered in villages yet 200 million mobile phone users are without bank accounts. That is the rate of growth of number of new mobile connections is more in rural India. The spreading of mobile banking products and systems will definitely contributes to erase the rural-urban divide and integrate rural economy with global economy.

Key words: Mobile banking products, Mobile banking Systems, Branchless banking Channel, Point- of- Sales Devices, Personal Identification Number, Mobile Network Operations, Bank in a box, Anywhere Bank Terminal, Bank on Wheels.
\end{abstract}

\section{Introduction}

In most of the developing countries the commercial banks have now realized the potential of mobile banking products and services to enable the rural people for accessing financial services. Vodafone, Airtel and Tata Telecom driven by international experience in Latin America, Africa and Philipines have already explored the feasibility to offer financial services through the mobile phones. Across the developing world, there are more people with mobile phones than with bank accounts. In 2011, there were over 5.3 billion phone users and which is close to $60 \%$ of the subscribers lived in developing world. Therefore, most of the entities having an international focus have turned to the mobile banking products as a potential platform for delivering financial services to the unbanked. The unbanked are people without formal bank accounts who operate in a cash economy. They are limited in their ability to takeout loans; maintain savings or make remote payments and these constraints definitely inhibit their economic opportunities. These obstacles can be removed to a great extent if the financial services are delivered by making use of mobile phones.

\section{Mobile Banking Products}

These are the financial services provided by banks through mobile phones. The deployment of financial services (mobilization of savings, withdrawals, loan disbursements and repayments, bill payments, remittances etc.) with the aid of mobile phones and non bank retail agents without requiring conventional bank branches. The mobile phones can be used to enter, display, process, store and transmit information as is done by computers, ATMs and Point- Of -Sale (POS) devices, which are the electronic network end-points that banks are using to serve the customers in urban and metropolitan centers. As an alternative delivery channel it has significant potential to enhance customer convenience, serving the existing customers better, facilitates unbanked, unprivileged and hard to reach customers with reduced costs. Mobile banking has the significant potential to address three critical issues for commercial banks in their effort to mobilize the rural savings and deploy credit to accelerate the process of agricultural and rural development such as widening and deepening outreach, reduction in costs at the level of banks and customers and customer satisfaction and convenience. Mbanking is about a decade old and confined to only few countries is a rapidly growing industry. There is now growing consensus among bankers and policy makers in developing countries to promote $\mathrm{m}$-banking' that offers a unique opportunity to serve low-income market and manage high volumes of low value transactions without investing in establishing extensive rural branch network. More importantly, Micro-Finance Institutions (MFIs) that have already been established since over a decade specifically to empower women and facilitate rural poor to access financial services in developing countries need to conceptualize and implement $\mathrm{m}$-banking services. 


\section{MOBILE BANKING MECHANISM}

To access m-banking facility, a customer has to visit a bank's branch or an agent accredited by the bank where he is properly identified as required by the law. He furnishes required information in the form, such as his name, address and mobile phone number and he provides an acceptable form of identification. Or, if he has already a bank account, he can register for mobile banking through a mobile phone by sending a text message to a particular number. Once the bank account is opened, the bank transmits the mobile-banking application wirelessly to the customer's phone. Now the customer registers his phone number and selects his personal identification number (PIN). He finds the mobile banking application, which will appear on the main menu of his phone. Once he launches the application, he will be asked to type his PIN. He can now begin transacting. He will be able to receive his salary, remittances and other transfers into his account and he will be able to make payments e.g., pay utility bills. Earlier the customer had to visit bank's branch personally to deposit cash or withdraw cash out of his bank account. If he now wants to withdraw cash then he has to visit the nearest grocery store that is acting as an authorized agent for his bank. The customer launches the application from the phone's menu, puts in his PIN and selects 'Withdraw' from the menu. He will be prompted to select the 'Account' from which he wants to withdraw, he enters the 'Amount' and then enters the 'Phone number' of the grocery store owner. The screen will prompt the customer to confirm the transaction by selecting 'OK' or replying his PIN. Both the customer and the store owner will get a message confirming that the customer's account is debited and the amount is transferred to the store owner's account.

\section{IMPLEMENTATION OF MOBILE BANKING}

For the successful implementation of m-banking, certain key factor are necessary, which are: (I) Committed Bank Management and its motivated, trained and empowered staff demonstrating the capability to manage the change, (ii) Viable business case focusing customer value proposition and driven by business demands, effective MIS, and efficient internal control system and not simply by the potential opportunities offered by technology, (iii) An enabling regulatory and development environment. Regulatory framework put in place by the Government and Central Bank in the country may need to be well defined and work as enabling environment to establish m-banking project. Two necessary but not sufficient' regulatory conditions must be in place such as authorization to use retail agents as cash-in/cash-out points and development of risk-based antimoney laundering and combating financing of terrorism rules adapted to the realities of remote transactions conducted through agents, (iv) Demonstrated and proven technology, with access to competent technology maintenance suppliers and well-functioning and stable MIS that can be integrated with the new technology. For customers, mobile banking presents a delicate balance between a conceptually powerful opportunity [being able to transact anytime, anywhere] and practical challenges (finicky menu sequences on a small screen and tiny buttons). With few exceptions, implementation of $m$-banking suffered seriously since many banks launched it without properly understanding customers' problems, how to address those problems, choosing a technology without identifying its purpose or implementing it without thorough analysis of its impact on the banks and customers or using the technology solutions without, changing their operations. Mobile Network Operators (MNOs) and some large banks have established m-banking projects as a part of their business on commercial scale, Mobile operator's active involvement is necessary to construct m-banking project to : (i) have $a$ customerfriendly, fast, and secure $m$-banking technology since the $m$-banking project needs to work under precarious conditions where people use low end handsets in areas with unreliable wireless connectivity, (ii) facilitate liquidity through a network of cash-in/cash-out agents retained from mobile phone operators' network of massmarket prepaid card retailers to work as cash agents and (iii) develop a highly efficient channel to create awareness of the service, widen customer outreach and mass-market growth and strong branding to overcome natural customer resistance to new technologies and associated security fears.

\section{MOBILE BANKING PRODUCTS: A NECESSITY IN RURAL INDIA}

While looking at the Indian banking Sector, with the implementation of financial sector reforms, the process of computerization in banking industry significantly changed the structure and texture of urban and metropolitan economy. Because of the inadequate formal banking infrastructure in rural areas the poor people in rural areas are inclined to use mobile phones to access the financial products and services. In India the rural population is around 741.6 million ( $74 \%$ of total population) whereas the rural penetration of banking services is only $18 \%$ of the total banking services in India. Out of 428 million deposit accounts in the country only $30 \%$ are in rural areas (Economic Survey 2012-13). In India over 30\% of the new mobile phone subscriptions every month are registered in villages yet 200 million mobile phone users are without bank accounts. Therefore it is the need of the time for the creation of a conducive environment and commitment for the application of mobile banking technology in rural India to erase the rural-urban divide and integrate our economy with the global economy. The branchless banking channels by making use of mobile phones would definitely relieve the rural poor from inconvenient travelling to and waiting in queue at distant branches and save the time and money. 
Banks and customers have to incur relatively very high costs for accessing financial services especially in rural India. While the Indian Banking Sector have been endeavoring their best to optimally utilize the rural banking infrastructure already created since 1969 for serving the rural population and accelerating the process of agricultural and rural development, the Government's policy on financial inclusion has been aimed at ensuring the monetary benefits to the marginalized sections of the society especially in rural areas through different banking products with ease, on time, without any leakages and intervention of middlemen. The evidences from the rural populations of developing nations shows the mass access to banking services such as mobilization of savings, withdrawals, loan disbursements and repayments, bill payments, remittances etc. From the international experience, Indian banks need to develop strategic action plans to harness mobile banking potential to enhance customer satisfaction and convenience, facilitate unbanked, unprivileged and hard to reach customers to access banking services at reduced costs.

\section{MOBILE BANKING PRODUCTS: INITIATIVES OF INDIAN BANKS}

Acknowledging the importance and responding to the initiatives of RBI on m-banking facility banks have begun to adopt Solutions such as biometric smart cards, mobile technology, point of sale and mobile bank to reach hundreds of the last-mile villages:

SBI conducted pilot projects in Mizoram, Meghalaya, Andhra Pradesh and Uttarakhand and developed a mobile banking kit called 'bank in a box' that comprises cell phone acting as a Point-Of-Sale [POS] machine, a finger print reader and a tiny printer-. This is used for opening 'no-frills' -accounts that are on smart cards issued to clients.

Corporation Bank initiated pilot projects on branchless banking in Karnataka, Andhra Pradesh, Tamil Nadu and Goa, surveying villages, assisting rural households to open bank accounts and issuing smart cards. It operationalised branchless banking units in 1200 villages during 2009-10 and mobilized deposits of? 25.97 crore by opening 'no-frill' accounts of about 5.47 lakh customers who were issued smart card keeping in view RBI's requirements of KYC/AML.

Indian Bank, Andhra Bank, SBI, State Bank of Hyderabad, Union Bank, Axis Bank, HDFC and Canara Bank are other banks using smart card-based technology solutions.

Integra offers iMFAST (Integra Mobile Financial Applications Secure Terminal), a portable teller machine that performs simple banking functions in rural areas. Operated by BCs in villages, the iMFAST solution, a hand-held terminal handling transactions concerning deposit, RD, withdrawal, loans, insurance, bill payments and booking train/bus tickets in rural areas, is currently used in over 500 locations by 15 banks (including Bank of Baroda, Canara Bank, Central Bank of India, Indian Bank and Vijaya Bank). Integra has issued ATM cards to three lakh customers in Karnataka, Madhya Pradesh, Tamil Nadu, Kerala, Andhra Pradesh, Maharashtra, Uttar Pradesh, Sikkim and Jharkhand.

HDFC Bank's "Anywhere Bank Terminal" at locations of Business Correspondents, besides 'Bank on Wheels' launched in 13 States (including Bihar, M.P., Rajasthan and U.P.) exclusively for the rural market facilitates low-income unbanked and underprivileged households to access financial services at affordable cost at their doorsteps using biometric ATMs. Bank reached more than six lakh customers beyond $200 \mathrm{~km}$ from its branches using the technological platform.

Grameen Financial Services piloted m-banking in Bangalore with 100 borrowers in partnership with Mcheck (Bangalore-based technology provider). After two years, it served more than 3,30,000 rural clients and planned to reach over two million by 2012. GFS incorporated technology, using Mifos, open source software developed by Aditi Technologies specifically for MFIs.

Union Bank of India added thousands of customers in remote villages through its BCs, such as Infrastructure Leasing and Financial Services, Drishti and Basix.(8) Under NREGS, banks in Andhra Pradesh conducted pilot projects to test 'leakage proof routing payments electronically to beneficiaries' accounts and transfer payments to the laborers through smart cards-based savings accounts.

Zero-M.A.S.S. Foundation in Karnataka launched a new generation biometric fingerprint authentication based solution, which has reached five million customers including beneficiaries of social security, pension scheme, NREGS, and SHG members in 18 States. The product suite, 'ZERO' is an end-to-end payment system to serves customers with small-value transactions including cash-in/cash-out, cashless transactions and remittances leveraging the security and connectivity of new generation mobile phones. mediation.

Ekgaon technologies offer software for accounting and MIS in case of SHG-based financial inter-

BASIX, in collaboration with banks, has set up physical infrastructure in the form of kiosks, which provides financial services and help local population to secure essentials and maintain contact with external world through Internet connectivity.

Mcheck provides services mostly to women, which include bank deposits, withdrawals, loan repayments, account balance and kirana shop payments. Mcheck has a vision to bring together the entire ecosystem of 
partners across the banking sector, banking service providers, as well as telecom operators to serve the base of users.

In 2009, MYRADA with the support of NABARD developed NABYUKTI, software to generate simplified MIS for promoting and linking SHGs.

\section{MOBILE BANKING PRODUCTS: GOVERNMENT INITIATIVES}

The Government of India and RBI having been committed to evolve a policy framework for optimum utilization of low cost mobile technology to accelerate the access of the poor households to banking and financial services have initiated, inter alia, following measures to encourage banks to adopt m-banking techno$\log$.

(1) In January 2006, the RBI permitted banks to utilize the services of NGOs, MFIs set-up under Societies/ Trust Act, Cooperative Societies Act and Section 25 Companies, registered NBFCs not accepting public deposits and post offices to act as Business Correspondents to provide banking services to clients on behalf of a bank, which include collection of small value deposits, disbursal of and recovery of loans of small value of principal and interest, receive and send small value remittances; cross-sell third party products such as micro-insurance, mutual funds and pension products, and engage in bill payments for services.

(2) RBI issued guidelines on m-banking transactions in October 2008 and has given approval to 32 banks to provide m-banking facility in the country, of which 21 have started providing these services.

(3) Established the Financial Inclusion Technology Fund with an overall corpus of Rs.5000 million to enhance investment in Information Communication Technology aimed at promoting financial inclusion, stimulating the transfer of research and technology in financial inclusion, increase the technological absorption capacity of financial service providers/users and encourage an environment of innovation and cooperation among stakeholders. The eligible activities, among others, cover : (i) encouraging user friendly technology solutions, (ii) providing financial support to technological solutions aimed at providing affordable financial services to the disadvantaged sections of the society (iii) creating a common technology infrastructure with comprehensive credit information, (iv) funding support to technologies facilitating the documentation for processing of loans, (v) providing viability gap/pilot project funding for unproven but potential technological interventions, (vi) conduct of studies, consultancies, research, evaluation studies relating to technological interventions for financial inclusion (vii) promoting seminars, conferences and other mechanisms for discussions, dissemination relating to financial inclusion technological interventions (viii) publication of financial inclusion technology literature and publicity material, (ix) Capacity building of persons of banks, post offices, State Government departments, MFIs, NGOs, Voluntary Associations and other stakeholders.

(4) Established the Financial Inclusion Fund with an overall corpus of Rs. 5000 million to support developmental and promotional activities with a view to securing greater financial inclusion, particularly among weaker sections, low-income groups and in backward regions/hitherto unbanked areas. The eligible activities, among others, cover (i) funding support for capacity building inputs to Business Facilitators and Business Correspondents.

(5) Established the Institute of Development Banking Research and Technology, Hyderabad, which has worked on several of technologies with a view to providing information to the banking and financial system. The institute has issued advisories to banks on types of software solutions that are required and also the issues relating to secure connectivity between the point of transactions and the base branch.

(6) The RBI Committee on Electronic Benefits Transfers suggested providing to each client Unique ID to prevent fraud.

\section{Conclusion}

The factual information and resultant evaluations revealing and substantiating the potential of mobile banking in India in order to ensure more meaningful inclusive banking and financial practices. With the implementation of Financial Sector Reforms the process of computerization in the banking industry significantly changed the structure and texture of urban and metropolitan economy. Now, it is the need of the time for concern and commitment to create enabling environment for application of m-banking technology in rural India to erase the rural-urban divide and integrate rural economy with global economy.

\section{References:}

[1]. Bhattacharya, Hrishikes. (1998). Banking Strategy - Credit Appraisal and Decisions - A Risk Return Framework. Delhi: Oxford University Press Indian Institute of Banking and Finance, Mumbai. (2010).

[2]. Atiya Parveen, Sobia Habib \& Saoud Sarwar "Mobile Commerce - New Way to Business" International Journal of Research and Development - A Management Review (IJRDMR) 2012Volume-1, Issue - 1, PP 37-40.

[3]. Banking Products and Services - October 2010 Indian Institute of Banking and Finance, Mumbai. (2010), Banking Products and Services - October 2010 .

[4]. Economic division, Department of Economic Affairs, Ministry of Finance, Government of India. (February 2013), Economic Survey 2012-2013. 
[5]. Asish Srivastava, Commercial Banking in India 2009-10 Report Card, the Indian Bank's Association, 2010. Vol.5, 16-20.

[6]. Mathew, J.Sarkar, varshney, “M-Commerce Services: Promises and Challenges" Communications of AIS, Vol.2004 Issue-14, PP 111 .

[7]. George S. Oreku, "Mobile technology interaction to e-Commerce in promising of u-Commerce."

[8]. www.nasscom.org

[9]. www.bankingnetindia.com

[10]. www.financeindiamart.com

[11]. www.iba.org. 